\section{University of Colorado 1976 Field Season in Eastern Baffin Island}

A large programme was carried out during the summer of 1976 by faculty members and graduate students from the University of Colorado's Institute of Arctic and Alpine Research (INSTAAR) and Department of Geological Sciences.

The research included studies of various aspects of Quaternary geology and chronology, investigations of micropalaeontological fauna from raised marine sediments, studies of weathering and of the role and significance of tors on hill summits (sometimes associated with erratics), and coring of lake sediments. Associated research included studies of cliff erosion, of changes in soils through time, on associations between microclimate and vegetation, and on Eskimo sites and archaeology.

Research was concentrated in four primary areas: Broughton Island, including the area south to Canso Channel and north to Kivitoo; Pangnirtung and Kingnait fiords; Sunneshine Fiord and Cape Dyer; and the fiords and bays of the northern Hall Peninsula.

\section{BROUGHTON ISLAND}

Poor ice conditions in late July and through to mid-August posed some problems, but nevertheless most objectives were achieved. The major field area took in the extensive cliff sections that extend nearly continuously from near the former settlement of Kivitoo northeastwards to Kangeeak Point and thence northwestwards to the mouth of Narpaing Fiord. The research, which started in late June, consisted in the main of mapping the surficial geology, delimiting marine features, describing in detail the stratigraphy in the cliff sections, and collecting shells and peats for dating by radiocarbon, $\mathrm{U}$-series and amino acid. In addition, pollen, foraminifera and mollusca were collected for analysis. Several buried soils and peats were located which will serve to increase knowledge of the environments in the eastern $\mathrm{Ca}$ nadian Arctic during, before and after the last interglacial. They should allow biostratigraphic correlations to be made between the Kivitoo sections and those further north near Clyde River. Similarly, the investigation of the benthic foraminifera in the various marine units in the cliffs should permit correlation between Clyde River and the area of Broughton Island1,2,3.

Samples of soil and tills were collected for determination of minerology and the devel- opment of a semi-quantitative index of age based on changes in various ferrous minerals.

The "Boas" Glacier was revisited in late summer and a weather station established on the col between Quajon and Narpaing Fiords. Stakes were drilled into the glacier for future mass-balance studies. The mass balance for the 1975-76 balance year was shown to be slightly positive to being in balance.

The recent (last 1000) years rise of sea level is causing extensive cliff erosion along many parts of the northern coast of Cumberland Peninsula. A project was commenced for the measurement of cliff retreat and the study of nearshore coastal and beach processes.

Research on and around Broughton Island focused on aspects of weathering in Arctic climates, in terms both of soil chronosequences and of the origin and age of tors that frequently occur on hill summits. Erratics are to be found in association with some of the tors, indicating that the latter were glaciated at some time. The two opposing hypotheses for explaining the sequence, time or a cold-warm ice division, are at present the subject of active debate.

\section{CAPE DYER AND SUNNESHINE FIORD}

The area was revisited for the second year. Poor ice conditions in the fiord curtailed some field operations. Research continued on the Quaternary geology of the area and on the extent during the Little Ice Age of thin, permanent snow cover. Another fossiliferous locality was discovered near the DEW Line ship terminal and is being dated by the amino-acid method. Echo soundings in Sunneshine Fiord indicated the presence of a submerged terrace at a depth of about 55 metres. A relative glacial chronology has now been developed which is derived from amino-acid ratios from three localities and associated with the better-dated sequence around Broughton Island.

\section{PANGNIRTUNG AND KINGNAIT FIORDS}

The emphasis here was on a study of the Holocene fluctuations of local cirque glaciers and mountain glaciers, and in addition a weather station was erected at the margin of a small glacier near Overlord Peak. The mass balance for the 1975-76 balance year was slightly negative.

Research continued on the Holocene glacial and climatic fluctuations. A 2.5-metre core was taken through lake ice at the mouth of Pangnirtung Fiord, and many replicate cores were taken in small tarns below a small cirque glacier. Changes in lithology and pollen content will be used to compare this rec- 
ord with that of the Neoglacial moraines, dated by lichenometry. Further excavations of a section near Windy Lake, Pangnirtung Pass, were made and samples collected for further radiocarbon and pollen analyses. Finally, a survey was made of Neoglacial moraines in a major valley entering Kingnait Fiord. Several nested moraines were mapped in detail and lichen measurements made for age determinations. There is evidence in this area of early Neoglacial advances probably older than 2500 B.P.

\section{NORTHERN HALL PENINSULA}

The coast of northern Hall Peninsula was mapped over a period of about four weeks. A major moraine system had been mapped on air photographs and several sites were located where the moraine was associated with fossiliferous glacio-marine sediments. Provisional amino-acid ratios suggest that the shells are Holocene in age. The marine limit was found to decline down Cumberland Sound and eventually to reach present sea level. Echo-soundings seaward of this point indicated that the glacio-marine deltas associated with the moraine belt are indeed submerged.

\section{ACKNOWLEDGEMENTS}

The research was primarily funded by a grant from the Geology Program of the U.S. National Science Foundation (continuation of GA-41562). Other essential support was provided individuals from the Penrose Research Fund, Geological Society of America,
Sigma Chi, the Explorers Club, the American Alpine Club and the Arctic Institute of North America. We wish to thank people in Parks Canada, the settlements of Pangnirtung and Broughton Island, and DEW Line officials for assistance and support of various kinds. Professor Brian Bird, McGill University, organized the study on cliff retreat.

\section{J.T. Andrews \\ INSTAAR and Department of Geological Sciences \\ University of Colorado \\ Boulder, Colorado 80309 \\ U.S.A.}

\section{REFERENCES}

1Andrews, J. T., Feyling-Hanssen, R. W. Miller, G. H., Schlucter, C., Stuiver, M. and Szabo, B. J. 1976. Alternative models of early- and middle-Wisconsin events, Broughton Island, Northwest Territories, Canada: toward a Quaternary chronology. In: Easterbrook, D. J. and Sibrava, V. (eds.), Quaternary Glaciations in the Northern Hemisphere. Bellingham, Washington: International Union of Geological Sciences (International Geological Correlation Program 73/1/24, Report no. 3. pp. 28-61.

2Feyling-Hanssen, R. W. 1976. A Mid-Wisconsinian Interstadial on Broughton Island, Arctic Canada, and its foraminifera. Arctic and Alpine Research, 8: 161-82.

3Feyling-Hanssen, R. W. The Clyde Foreland Formation, micropalaeontological study of Quaternary stratigraphy. Maritime Sediments (in press). 